Journal of Development and Communication Studies, Vol. 8. No. 1, January -June, 2021 ISSN (Online \& Print): 2305-7432. http://www.devcomsjournalmw.org

\title{
Relevance of Cocoa Life Project Interventions to Community Development in Rural Ghana: Exploring the Views of Beneficiaries in Wassa East District
}

Daniel Odoom, Faculty of Integrated Social and Communication Sciences, Ghana Institute of Journalism, Accra, Ghana. Email: odoomd@gij.edu.gh

\begin{abstract}
This study investigated the relevance of Cocoa Life Project interventions implemented by World Vision Ghana to the development of beneficiary communities using the Wassa East District as a case. The views of members who were mostly farmers, gari processors, soap makers, and members of village savings and loans associations from beneficiary communities were considered in a sequential-dependence mixed method research approach. A total of 406 respondents were selected using stratified, simple random and convenience sampling methods, with 84.2 percent response rate for the quantitative data. Research instruments were interview schedule and focus group discussion guide. Means and standard deviation were used for quantitative analysis whilst thematic analysis was done for the qualitative data. The study observed that WVG's project interventions were highly relevant to education, business development, financial literacy, microcredit facilities, agriculture, and livelihood diversification within beneficiary communities. Also, awareness creation was one of the main communication tools WVG relied upon in promoting community development in the district. Though the interventions led to behaviour change, there were concerns with the overall change in behaviour within the communities. Besides, beneficiary communities had diverse development needs which could only be understood through appropriate and well-planned development communication strategies and approaches. As part of the recommendations, WVG should collaborate with Mondelez International and local authorities to come out with measures to improve upon job creation, behaviour change at the community level, health care services, and water and sanitation in Cocoa Life communities.
\end{abstract}

Keywords: Community development, development communication, NGOs, beneficiary communities, interventions, alternative development theory 

share and redistribute this work provided that the author and the Journal of Development and Communication Studies are fully acknowledged. Users may not tweak or remix and offer this work for sale. The full license may be accessed at https://creativecommons.org/licenses/by-nc-nd/4.0/

To cite this article: Odoom, D. (2021). Relevance of Cocoa Life Project Interventions to Community Development in Rural Ghana: Exploring the Views of Beneficiaries in Wassa East District. Journal of Development and Communication Studies, 8(1), 22-48, https://dx.doi.org/10.4314/jdcs.v8i1.2

\section{Introduction}

Development seeks to bring about quality changes in the lives of the people. Across the globe, nations institute measures aimed at improving the wellbeing of their citizens (Odoom, 2016; Ruttan, cited in Opoku, Kyeremeh \& Odoom, 2014). However, in almost the world over, states with limited finances, poor governance, mismanagement and corruption have failed to ensure development for all of their citizens. Where states cannot provide sufficient goods and services or create enabling environments that help citizens to improve their lives, or where disadvantaged groups are excluded from existing state institutions, alternative channels of service provision and or holding governments to account must be found. One such form of alternative development especially since the 1980s has been the interventions of nongovernmental organisations (NGOs) (Banks \& Hulme, 2012; Brass, 2010; Okorley \& Nkrumah, 2012). Thus, theoretically, the alternative development approach locates the place of NGOs in development service delivery.

Particularly, NGOs are increasingly asserting themselves as the third force in the development drive of nations. NGOs have and continue to show interest in providing development interventions aimed at improving the lives of people especially in rural areas. Through their interventions in the areas of education, health, governance, gender equality, environment, human rights, agriculture and enterprise development, NGOs have been viewed as a potent force in efforts to improve the conditions of people in rural communities. The increasing recognition of the place of NGOs in development has led to an overwhelming number of NGOs whose programmes, projects and activities are largely funded by donor community, corporate bodies and other development partners (Odoom, Yeboah, Opoku \& OseiWusu, 2018; Okorley \& Nkrumah, 2012).

Over the past three decades NGOs have been increasingly advocated as a means through which the gap between citizens' needs and existing services can be 
bridged. NGOs have played a continued vital role in the development sector, and are widely praised for their strengths as innovative and grassroots-driven organisations. NGOs are seen as having the desire and capacity to pursue participatory and peoplecentered forms of development and to fill gaps left by the failure of states across the developing world in meeting the needs of their poorest citizens (Banks \& Hulme, 2012; Barr, Fafchamps \& Trudy, 2005; Lewis \& Kanji, 2005).

NGOs continue to rise in prevalence and prominence. Although global figures are hard to come by due to the lack of a coordinating body, Epstein and Gang (2006) revealed that for all Development Assistance Countries, official development assistance (ODA) to NGOs increased from US\$928 million to US\$1246 million between 1991 and 2002. This figure shows a 34 percent increase within the said period and the number of international NGOs grew by 19.3 percent. Beyond the rapid increase in the number of NGOs, there has been a concurrent trend towards growth in the size of NGOs, particularly justifying the rising interest in NGOs as a development alternative (Edwards \& Hulme, 1996). In essence, NGOs are now a major actor on the development stage, in some cases receiving as much or more funding than their government counterparts (Brass, 2010, 2012).

Continued donor distrust and frustrations with states generated and fuelled interest in NGOs as desirable alternatives, viewing them favourably for their representation of beneficiaries and their role as innovators of new technologies and ways of working with the poor (Barr et al., 2005; Lewis, 2005; Murray \& Overton, 2011). Africa experienced its NGO boom a decade later, starting in the 1990s (Hearn, 2007). For example, Kenya experienced a rapid increase in registered NGOs, from 400 in 1990 to over 6,000 in 2008 (Brass, 2011). Likewise, in Tanzania, the 41 registered NGOs in 1990 had increased to more than 10,000 by 2000 (Hearn, 2007). In some countries, such as Uganda, the NGO sector is viewed with mixed feelings, including rampant suspicion that the public good is not the primary motivation fuelling their operations (Barr et al., 2005).

Again, political influences have been suggested as a strong influence on NGOs in Africa, with NGOs joining the patronage networks of political leaders (Brass, 2012). However, the good governance agenda which embraces the language of democracy, human rights, and public participation (Murray \& Overton, 2011) is a consolidation of the centrality of NGOs in the development landscape. As a result, since the year 2000 a new aid regime has evolved which promises to move beyond growth-focused neoliberalism towards greater consultation between donors and recipients and a greater focus on poverty and responsibility for nation-states (Barr et al., 2005; Murray \& Overton, 2011).

A prominent NGO that has contributed to the development of communities especially in rural Ghana is the World Vision International (WVI). WVI is a Christian relief, development and advocacy organisation dedicated to working with children, 
families and communities to overcome poverty and injustice. Inspired by their Christian values, they are dedicated to working with the world's most vulnerable people. World Vision provides a range of interventions tailored to the context, including programmes in education, health, economic development, microfinance, agriculture, water and sanitation. World Vision also works to ensure that governments are implementing needed measures to enhance health care delivery in rural areas of Africa. Again, as part of fulfilling the Sustainable Development Goals (SDGs), World Vision International (2016) believes that sustainable development starts and ends with healthy, nourished and well-educated society. It is recognised that increased interventions in areas such as HIV and AIDS, water, sanitation and hygiene are crucial in the attainment of SDGs. For instance, a 2015 census shows that World Vision is supporting about 220,370 Community Health Workers in 48 countries including Ghana (World Vision International, 2016). World Vision Ghana (WVG) provides development interventions through the active collaboration and partnership with both international and nations organisations.

Cocoa Life Programme is a holistic programme aimed at creating a sustainable cocoa supply through transforming the lives of cocoa farmers and communities at scale. Cocoa Life Programme has a sole vision of ensuring thriving cocoa communities through partnerships with key stakeholders. Based on its commitment to this program, Cocoa Life Programme's approach incorporates three main principles. They are holistic and farmer centric, committed to partnerships, and aligned with its sourcing (Mondelez International and Cocoa Life, 2013). Through the creation of partnerships with communities, governments, national and international nongovernment organisations (NGOs) and supply chain partners, Cocoa Life Programme assists communities in developing real solutions for community transformation. In November 2012 Cocoa Life Project was launched by Mondelez International with the aim of investing $\$ 400$ million USD by 2022 to empower at least 200,000 cocoa farmers and reach over one million community members in six key cocoa growing origins: Côte d'Ivoire, Ghana, Indonesia, India, the Dominican Republic and Brazil. It is the expectation of Mondelez International the Project will link cocoa farming with community development. A variety of initiatives exist under the Project to support farmers in local communities, help them to cultivate more resilient crops, and create real impact across our cocoa communities (Mondelez International, 2014; Mondelez International and Cocoa Life, 2013).

Cocoa Life focuses on linking cocoa farming with community development. The programme entails a variety of initiatives aimed at supporting farmers in rural communities, assisting them to cultivate stronger, more resilient crops, and also creating real impact across cocoa communities. As a build-up on the Cadbury Cocoa Partnership which was founded in Ghana in 2008, Cocoa Life Programme links the beginning and end of the cocoa supply chain to enable farmers see how their cocoa 
crop largely contributes to the chocolate the world enjoys (Mondelez International Progress Report, 2015). This experience has shown MI that while these issues are complex and there are no quick fixes, Cocoa Life can be successful in tackling them if the organisation works with partners and the cocoa communities on a long-term basis, guided by a clear and distinctive approach, and underpinning values and principles. It is from this work in Ghana and insights from other activities in cocoa origins, with certification schemes and from others in the cocoa industry that the Cocoa Life approach was developed (Mondelez International, 2013, 2014).

Mondelez International's Cocoa Life approach is designed to guide the scale up of its origin development in all the cocoa origins of the company and to ensure its cocoa purchasing supports the investments made in beneficiary nations. The needs in each origin are unique, and the local outcomes the company seeks, and the programmes it will develop with its partners, are specific to each origin. Nevertheless, there are some common processes in how the company goes about it, and how it ensures its investment is having an impact, which is the Cocoa Life approach. All key stakeholders including NGOs which are the main implementing partners (IPs), Cocoa Life, governments, beneficiaries and external advisors provide inputs to make the programme a success. They are expected to directly participate in the various interventions implementing partners such as NGOs undertake (Mondelez International Progress Report, 2015).

Cocoa Life Programme focuses on five main areas namely, farming, community, livelihoods, youth and environment. Mondelez International has made a long-term, high-level and public commitment to the Cocoa Life Programme. Concerning farming, Cocoa Life helps farmers benefit from access to the most up-todate agricultural information. Practices including planting trees at optimum density, using shade trees, starting seedlings in nurseries, and protecting trees from infestation and infection are expected help to increase yields and plot value. In this, farmers' income level will increase. Regarding community, Cocoa Life provides various supports to men and women to work together to transform their communities by developing action plans that can bring about changes to the community that they want to see confidence, and a sense of opportunity and ownership emerge as communities begin to thrive. This is anchored on their belief in a shared vision of uniting communities (Mondelez International and Cocoa Life, 2013).

Also, through its livelihoods agenda, Cocoa Life supports farming communities to create new entrepreneurial businesses in sectors complementary or different than cocoa. They look at ways to support improved access to micro-finance, together with training on financial literacy and how to manage additional income, allowing farmers to develop alternative sources of income and to reinvest in their businesses. Through its youth empowerment programme, Cocoa Life works towards eliminating child labour by helping communities tackle its root causes. They also aim 
to ensure that cocoa farming becomes an attractive business for the next generation. Thus, the organisation works to inspire young people about a future in cocoa farming. Finally, under environment Cocoa Life believes that protecting the landscapes in which cocoa is grown to maintain ecosystems and providing viable environments and farming land for future generations are essential in achieving a thriving community. The various interventions towards these key areas are to ensure, among other things, the development of beneficiary communities (Mondelez International and Cocoa Life, 2013). Among the NGOs charged with the responsibility of designing and implementing interventions to achieve the vision of Cocoa Life Programme is the World Vision Ghana (WVG). As part of its strategies, WVG, an implementing partner, is expected to undertake interventions relevant to the development of communities within its operational zones.

\section{Rationale}

WVG started operating in the Wassa East District (WED) in 2003. As part of its rural development efforts in the district, WVG's concentration has been on core areas such as education, health, water and sanitation, income generation, agriculture and local governance. In the area of education, WVG has been helping children go to school, by building and renovating schools, providing desks, textbooks and other stationery, creating awareness about girl child education and early school enrollment age and awarding scholarships to hundreds of needy children in the WED (WVI, 2016). In the area of health and nutrition, WVG provides quality, accessible health services to children and their families, including immunisation programmes and de-worming treatment to several children (WVI, 2005, 2016). With regard to economic empowerment in the district, WVG supports micro-enterprise development by providing micro-credit financing, offering skills training and linkages to markets and they also increase food security by building capacities of farmers in scientific methods of crop and animal production, resulting in boosted productivity and increased incomes (WVI, 2005). WVG also provides vocational and technical skills and advises farmers on improved production technology in farming (WVG Report, 2014, 2016).

As already stated, WVG has been a major implementing partner of Cocoa Life Project sponsored by Mondelez International. One of the districts in which WVG first started implementing the Project is Wassa East District. For over six years, WVG implemented several development interventions in the WED in areas such as education, agriculture, water and sanitation, financial literacy, gender equality, livelihood programmes, among others. For example, in education, WVG constructed educational facilities and also provided awareness creation on the importance of education in the District. In agriculture, the organisation and Cocoa Life Division provided training on modern farming practices to farmers whilst in financial literacy training programmes such as savings and access to credit facilities were offered to 
community members. WVG also constructed pipe-borne water and dug-out wells to communities and also helped to develop community action plans. Several other interventions were provided by WVG under the Cocoa Life Programme to over 40 communities in the District (WVI, 2016; WVI, n.d.). Ever since the NGO started implementing the Project no concerted effort has been made to comprehensively tell the Cocoa Life Project story of WVG from the perspective of WED. Although some revelations were made about Cocoa Life Project in the District, the nation-wide nature of the research could not allow for any extensive analysis of the situation in the District. In particular, no extensive studies have been undertaken to empirically show whether or not the Project interventions have been relevant to the development of beneficiary communities in the WED. The prevailing situation makes it very difficult for one to fully appreciate the place of WVG regarding the success or otherwise of the Cocoa Life Programme in Ghana. This study, therefore, aimed at offering a comprehensive district-specific analysis of the relevance or otherwise of Cocoa Life Project interventions to community development in the WED. The paper also presents the theoretical implications the study has for effective development communication strategies and approaches, in particular, and development process, in general.

\section{Theoretical context}

As a historically constructed concept, community development has a multifaceted application. It deals with the physical, social, cultural, economic, political and environmental aspects of community. In practice, the concept has existed since the creation of societies where people lived a communal life (Marah, 2006). In contemporary history, community development can be traced back to the 1960s American war on poverty (Phillips \& Pittman, 2009, p.3). The crusade aimed at solving social problems among people through neighborhood housing development projects and citizen participation. In such manifestations, Bhattacharyya (2004) regards community development as a positive response to the historic process of decline of solidarity and civic participation. Community development can, therefore, be used to build social capital among people to overcome perceived 'common' social problems. Community development is also embedded in the historical epoch of imperialism and colonialism of Britain. Within this period, it was also used as a method to meet social and economic development to meet the new political and social expectations of the working class after the Second World War (Tett, 2010). Indeed, it was hoped that involving local people would encourage self-reliance, self-regulation and self-surveillance. In essence, it led to the promotion of popular education and solidarity (Tett, 2010).

In developing countries, particularly in Africa, community development can be traced back to the post-Second World War reconstruction with the measures aimed at enhancing the social and economic wellbeing of people (Phillips \& Pittman, 2009, 
p.3). Here, community development was used both as a tool to reduce poverty, disease and ignorance and to repress anti-colonial struggles. In places such Kenya, the colonial administration used community development as a veritable tool to control and channel the forces of anti-colonialism which dominated the political scene (Wallis, cited in Kamando, 2014). By the late 1950s, community development officers were mainly African who had worked as assistants. According to Kishindo (2001), community development in this region is mainly a rural phenomenon with focus on the creation of social infrastructure such as schools, health centers, roads, and bridges.

The situation in other places such as Tanzania was not much different. In Tanzania, the spirit of self-help practice was a vital part of community development drive; the practice upon which social services projects were based. As such, working and living together in the established ujamaa (collectively-run) villages were publicly promoted in order to simplify the provision of and access to social services. In the views of Collins, cited in Kamando (2014), the principles of rural development stipulated in the Arusha Declaration included values of self-help and self-reliant efforts which were expected to enhance community development. In this way, community development became a government-led self-help model, rather than the more independent grassroots (bottom-up) model (Kamando, 2014).

In the context of Africa, self-help schemes have become the reference point in the construction of primary and secondary schools especially after independence as part of community development. However, self-help activities became community development when they are included in the government's community development framework (Kamando, 2014). Gilchrist (2009, p.23) contends that community development is about interacting with people to assist them to make changes in their own lives. Community development is a participatory intervention that promotes self-help and service delivery when the state is unable to satisfy community aspirations. Community development in this context encourages people to unite with a national spirit of collective action to build the newly independent nation, alongside government interventions (Gilchrist, 2009; Kamando, 2014).

In the views of Kishindo (2001), and Kamando (2014), community development is as a process by which the efforts of the people themselves are combined with those of government institutions to improve the socio-economic conditions of the community. It focuses on issues such as agriculture, education, health, water and sanitation, and micro-enterprise projects. Other issues are governance, human rights, employment creation, and environment (Kamando, 2014; Kishindo, 2001; Swastik, 2012). Mulhall (2014) defines community development as a process of collective action often initiated by the members of a community in order to deal with identified problems or needs in their community. Phillips and Pittman (2009, p.6) conceive community development as both a 'process' and an 'outcome'. As a process, it focuses on developing and enhancing people's ability to take collective 
actions. As an outcome, it takes a collective action, which results in community improvement in physical, economic, cultural, social, environment, and political spheres. In order to ensure the realisation of community development aims, there is the need to fully utilise the existing knowledge or provide conditions for the people to collectively initiate and execute developmental activities that better benefit them (Kamando, 2014). Again, community development is viewed as the systematic process by which a group of people in a community mutually decides to initiate a planned intervention to change their own economic, social, cultural or environmental situation (Christenson \& Robinson, as cited in (Beaulieu \& Welborn, n.d.).

According to Gilchrist (2009), community development must be seen as a process of developing relationships with people, encouraging them to build relationships with each other to get things done and also educating them about the way they can best live together, and how they can best relate to ensure the full use of resources and power (p.101). In essence, community development practitioners are implored to create learning atmospheres that help local people to establish vital connections between their lives and the structures of society that shape the world they live in (Combat Poverty, cited in Mulhall, 2014; Ledwith, 2011). Thus, community development facilitates people empowerment for the attainment of collective goal. Empowerment by means of community development affects both individuals and the wider community network (Hautekeur, 2005).

To the United Nations, as cited in Swastik (2012), community development is a process of creating conditions of economic and social progress for the entire community with the active involvement and reliance of community initiatives. It entails efforts aimed at enhancing the socio-economic aspects of the people. However, in order to achieve this requires a conscious understanding of community needs and the active participation of community members. The objectives of community development strategies include improved living standards of people (Mellor, cited in Annor-Frempong, 2013); empowerment of individuals and groups of people to participate and cause a change in their own communities (Christenson, cited in Annor-Frempong, 2013); improved infrastructure, health and human resource development; poverty reduction; improved food security; and sustainable management of natural resources (Stiglitz, cited in Annor-Frempong, 2013). In situations where 'power' assumes an indispensable feature, community development becomes an implicit assumption that the organisation and structure of society are the cause of problems of powerlessness, alienation and inequality (Kamando, 2014; Ledwith, 2011). In this case, there is the need for redistribution of resources and power (Ledwith, 2011). In this way, community development becomes a vital factor in revolutionising the socio-economic problems for local actions and services to improve the larger society. Paulo Freire, as cited in Kamando (2014), explains that grassroots participation is key in societal change. 
It is believed that if the local people are engaged in a process of critical consciousness to understand the world differently and to unite in collective action to create a better reality, community development will become a reality. Freire concluded that people have capability to engage in critical discussion and negotiations especially when the issue is of relevance to their very existence (Combat Poverty, cited in Mulhall, 2014). In the opinion of Beck and Purcell (2010), such situations empower people and ensure self-reliant relationships among actors in the process of community development. To this end, Rifkin and Pridmore, as cited in Kamando (2014) call for the involvement of local people in planning, implementing and evaluating development interventions which affect their lives. Development practitioners, researchers and stakeholders have come out with various approaches to community development. Differences in conceptualisation of approaches exist due to diversity of opinions and positions. This study discussed five main approaches to community development. They are the technical assistance, the conflict, the self-help approaches, needs-based approach, and the asset-based approach. The technical assistance approach involves the delivery of programmes or interventions to improve the lives of people. It relies on top-down understanding of dealing with obstacles confronting communities. This approach employs experts to design development services and deliver them in targeted areas. It focuses on the task to be performed, and it is assumed that the answers needed are scientific, which only the experts can provide. This approach offers very little room for local participation in the planning and design of the interventions since it sees the local citizens as consumers (Beaulieu \& Welborn, n.d.).

The conflict approach focuses on deliberate use of confrontation by professional organisers to cause people to identify and address their common needs. This approach has the redistribution of power as its goal. It also entails confronting the forces that impede efforts to solve community problems. It again fosters suspicion of those who have formal community power and assumes power is never given away, rather it has to be taken through conscious efforts of the affected people (Beaulieu \& Welborn, n.d.). Moreover, the self-help approach is the approach which encourages people to work together for the attainment of common goal of the community. With this approach, development actors employ collaboration to provide important needs and services. They also lay emphasis on the processes required to improve the community. Little emphasis is placed on the task or goal since a proper execution of the process will invariably lead to goal accomplishment. Here, the beneficiaries are the integral aspect of the processes of development, right from planning to the evaluation stage of the projects (Beaulieu \& Welborn, n.d.).

On the other hand, the needs-based community development approach (NBCC) often looks at deficits in communities. With this approach, community members in such situations are defined and see themselves as deficient and incapable 
of taking charge of their own development within the community (Kamando, 2014; Mathie \& Cunningham, 2003). Mathie and Cunningham (2003) state that an NBCD approach is based on a 'one-sided negative view', which instead of contributing to community capacity building, hugely compromises it. This approach is a conventional way of achieving community development where local people identify numerous issues, problems or needs in their community and work out how to address them (Haines, 2009, p.39). Usually, however, the local authorities identify myriad of issues and present them to the local community as problems to be fixed. In many poor communities with high rates of unemployment, it is not uneasy to pinpoint problems or deficits. Kretzmann and McKnight, as cited in Kamando (2014), stated that even leadership at local levels is judged on how communities attract many resources, rather than how resources can help the community to become self-reliant. Leaders therefore utilise the severity of problems they face as the best means of attracting resources and funds for the development of their communities.

Despite its importance, the NBCD has some deficiencies. In support, according to Haines (2009), when local leaders, practitioners and community members focus on problems, they tend to concentrate only on what is missing in communities and ignore the causes of problems, as well as the community's own problem solving abilities and local assets that can be tapped for development (Kamando, 2014). Again, with NBCD, power tends to become hegemonic; whereby, the powerful decide the kind of interventions to make and the powerless implement them in the name of a 'participatory approach'. In addition, Mathie and Cunningham (2003) argue that government agencies and NGOs have the tendency to set the terms of community engagement which is often limited to consultation rather than truly participatory community decision-making. Lastly, as an alternative approach, the assets-based community development approach $(\mathrm{ABCD})$ was propounded to deal with the deficiencies inherent in NBCD, which exclusively focus on needs and problems. By nature, the $A B C D$ approach is inclusive which recognizes the capacities of local people and their associations in developing powerful communities (Kretzmann \& McKnight, cited in Kamando, 2014). This approach focuses on the need to recognise and exploit the existing assets sufficiently, in terms of a community's strengths and capacities; thereby, promoting citizen-led initiatives (Haines, 2009; Russell, 2009). This is done with the conscious awareness of the problems in the community. For instance, $\mathrm{ABCD}$ begins with the strengths and achievements of communities. By so doing, $\mathrm{ABCD}$ frowns upon discouraging people in the solving of overwhelming lists of endless problems and instead, builds positive perspectives on community (Haines, 2009).

According to Mathie and Cunningham (2003), the value of ABCD lies in the fact that people in communities have the capacities to organise and drive their own development processes by identifying and mobilising existing assets, thereby 
responding to and creating local economic opportunity. They however concede that often, these assets are unrecognised. Assets as defined by Haines (2009) are resources including any useful or valuable quality, person, or advantage. In effect, individuals, local institutions and organisations constitute valuable assets. ABCD maintains the idea that individuals within the community are potential assets to grow in the longterm (Haines, 2009; O'Leary, Burkett \& Braithwaite, 2011). Dongier, Domelen, Ostrom, Rizvi, Wakeman, Bebbington, Alkire, Esmail and Polski (2002) assert that in the course of ensuring community development, local people have to be treated 'genuinely' as both assets and partners. This is because, local people have various skills and knowledge which are very useful for effective community development. However, for local people to effectively build on existing capacities and work as proper development partners, they need empowerment. This explains why 'power re-allocation' to local communities has been seen as central to ABCD (Kamando, 2014; Mathie \& Cunningham, 2003). In fact, the local people have been denied the power of decision-making due to the influence of $\mathrm{NBCD}$ and other related top-down approaches to community development initiatives. $A B C D$ seeks to ensure the reallocation and sharing of powers by all actors for effective community development.

Scholars such as Mathie and Cunningham (2003) have cautioned both governments and NGOs to avoid the temptation of using ABCD as a self-serving initiative; rather, they have to perform a role crucial to the social obligations inherent in government-citizen/community relationships. This has to go hand-in-hand with a clearly defined rules based on transparency, commitment and accountability. This is one sure way they can protect community resources from corruption by the powerful forces (Dongier et al., 2002; Kamando, 2014). Again, even though ABCD helps communities to plan activities with or without outside intervention ( $\mathrm{O}^{\prime}$ Leary et al., 2011), outside help for a suffering community is imperative. Although, projects may be led by citizens with outside agencies playing a supporting role, community development can be effectively attained (Russell, 2009). The essence of citizen-led initiatives occurs when the crusade for community development begins from inside with people's awareness of their strengths. In fact, every community which is rural, isolated or poor has resources or assets which when invested appropriately create new resources in the form of 'capital' (O'Leary et al., 2011, p.7). In the context of ABCD, distinguishing tangible assets from intangible ones is viewed vital in making the intangible more visible (Haines, 2009; O'Leary et al., 2011). Although intangible assets such as experiences, personal strengths, culture, traditions, skills and knowledge seem vague, they are vital for the well-being of people and communities.

Haines (2009) has identified some seven forms of capitals; namely: physical or public, financial, social, human, natural or environment, cultural and political capitals. Communities can use human and social capitals to build other forms of capitals such as financial need for their development. Human capital refers to the 
skills, talents and knowledge possessed by community members. General education, experiences, skills, etc. are examples of human capital. However, the extent to which people's strengths, knowledge and skills are utilised has huge implications on viable community development (Haines, 2009; Kamando, 2014). According to Haines (2009), physical or public capital includes roads, buildings and natural resources, schools, colleges and prisons which are often the property of the community. This type of capital relies heavily on the extent and capacity of human and social capital among the community members. Unlike physical capital, social capital involves the social relationships and connections within the community. Its ingredients include trust, norms and established social networks (Kamando, 2014). In community development, as Haines (2009) argues, social relationships are s critical elements for a project's success, as they impact on mobilisation for community participation. Social capital is relevant in the context of $\mathrm{ABCD}$ in community development activities. $\mathrm{ABCD}$ pays much attention to the talents of individuals as well as the social capital inherent in the relationships, local association and informal networks (Mathie \& Cunningham, 2003).

\section{Methods}

The sequential-dependence mixed method research approach was used. The population was drawn from community members who were mainly farmers, members of Village Savings and Loans Associations (VSLAs), gari processors, and soap makers. The first stratified the beneficiaries into four strata, namely farmers, members of the VSLAs, GPGs and soap makers. For the farmers, the researcher focused on the various groups in the communities which benefited from the project interventions. There were 456 active members of farmer groups in the beneficiary communities out of which 213 were involved in the study using Yamane (1967) sample size determination formula through simple random sampling method (lottery method). A similar was used to select 92 active members of the VSLAs in the communities from a population of 120 using simple random sampling method (lottery method).

Again, 63 active members of GPGs were involved in the study using Krejcie and Morgan (1970) sample size determination table at a confidence level of 95\% through simple random sampling method (lottery method). Unlike the other beneficiaries, soap makers did not have recognised groups with clear leadership structures. Thus, getting all of them was very difficult. Besides, though WVG trained community members on soap making as an alternative source of income generation activity many of the beneficiaries were not into soap making because of the capital required to properly engage in such venture. As a result, the researcher relied on convenience sampling method to select 38 beneficiaries who were into soap making. A total of 406 respondents made up of 213 farmers, 92 members of Savings and Loans Groups, 63 Gari Processors, and 38 Soap Makers for the study. The quantitative data 
had a response rate of 84.2 percent. Data collection instruments employed were interview schedule and focus group discussion (FGD) guide. The interview schedule was developed based a scale of: 5=Very Highly Relevant, 4=Highly Relevant, 3Moderately Relevant, 2- Lowly Relevant, and 1-Verly Lowly Relevant. Two FGDs were organised in the two Area Councils in the District where the interventions were mostly implemented. The Area Councils are Daboase Area Council and Ekutuase Area Council. Instruments were pre-tested in the Fanteakwa District which was the only district aside WED where WVG first implemented the Cocoa Life Project interventions. For the quantitative data, means and standard deviation were used for analysis whilst in the case of the qualitative data, transcribed data were analysed thematically.

\section{Results and Discussion}

This section presents the results of the study in two parts. The first part looks at the results based on the research aim whilst the second part situates the results within relevant theoretical frameworks. Regarding the first part, the perceived relevance of the project interventions based on diverse aspects of community development such as education, business skills, agriculture, employment, financial literacy, health, water and sanitation, and behaviour change were examined.

\section{Relevance to the development of education}

Table 1 shows that the interventions were highly relevant to the development of education in the beneficiary communities. For example, respondents stated that the Project was highly relevant in expanding access to education $(\mathrm{M}=4.03, \mathrm{SD}=0.90)$ and awareness creation on the importance of education in the communities $(\mathrm{M}=4.21$, $\mathrm{SD}=0.50)$ in the District. Moreover, beneficiaries saw the Cocoa Project interventions of WVG as approximately highly relevant $(\mathrm{M}=3.67, \mathrm{SD}=1.12)$ to the construction of educational infrastructure. The results from the FGDs showed that WVG contributed to the development of education in the beneficiary communities. For instance, the beneficiaries in the Ekutuase Area Council who were part of the FGDs said:

Project interventions of WVG have been very relevant to the development of our communities in areas such as expanding access to education, and awareness creation on importance of education. For example, we now have ICT centres in schools of some communities.

The participants from Ekutuase Area again said, "So much awareness has been created about the importance of education. Some officers from WVG used to meet the community once in a while to educate us on the danger of child labour. They also built teachers' bungalow for our teachers". 
Table 1: Views of respondents on the relevance of the project interventions to community development

\begin{tabular}{lcc}
\hline \multicolumn{1}{c}{ Activity to ensure community development: } & Mean & Standard Deviation \\
\hline Training on modern farming practices & 4.30 & 0.46 \\
Diversifying sources of earning living & 4.26 & 0.45 \\
Rehabilitation of farms in the community & 4.26 & 0.45 \\
Awareness creation on importance of education & 4.21 & 0.50 \\
Provision of microcredit facilities to people & 4.07 & 0.61 \\
Expanding access to education in the community & 4.03 & 0.90 \\
Training on financial literacy & 4.03 & 0.90 \\
Skills training on business development & 4.00 & 0.64 \\
Construction of educational infrastructure & 3.67 & 1.12 \\
Creation of career opportunities & 3.40 & 1.08 \\
Expanding access to safe and clean water & 3.40 & 1.08 \\
Capacity building on local level leadership & 3.40 & 1.08 \\
Support for community action & 3.40 & 1.11 \\
Behaviour change towards community activities & 3.39 & 1.08 \\
Public awareness on sanitation practices & 3.34 & 1.16 \\
Expanding access to health care services & 3.16 & 1.19 \\
Capacity building on community planning & 3.14 & 1.21 \\
\hline Grand & 3.49 & 0.82 \\
\hline Means were calculated from a scale of: 5=Very Highly Relevant, & $4=$ Highly \\
Relevant, $\quad$ 3-Moderately Relevant, 2- Lowly Relevant, 1-Verly & Lowly \\
Relevant & &
\end{tabular}

Participants from Daboase Council stated that awareness creation on education coupled with educational infrastructure such as ICT centres in schools help to boost education in the communities. In the words of beneficiaries from Daboase, "In the past, very few people sent their wards to Senior High School (SHS) but now, because of awareness creation on education, many people are trying hard to send their wards to SHS." Also, from Daboase Area it was indicated, "WVG provided include ICT centres which our children make use of when they are in school". In essence, the results from both the qualitative and quantitative studies show that the Project largely contributed to the development of education in the District. The findings on education are consistent with previous studies (Kombian, 2008; Quaicoo, 2006; Stromquist, 2002) which found that NGOs are active in the provision of educational facilities. Also, the results on educational services corroborate Farrel and Hartwell (2008), and USAID (2009b) revelations that NGOs in Ghana are into the provision of educational services. Further, the results are in line with Enyioko's (2012) study in Nigeria which 
discovered that development actors such as NGOs play a crucial role in the provision of educational services. Again, WVG's efforts in the education sector are similar to what other NGOs are doing globally (ActionAid International, 2013). Awareness creation is a critical communication tool used to deliver development services (Mefalopulos, 2005; Quarry, 2006; UNICEF, 2008).

\section{Relevance to the development of business skills}

Business development is key in any sustainable development agenda. Thus, the study also explored how relevant the interventions were to business development in the communities. The researcher observed that the interventions of WVG under the Cocoa Life Project were highly relevant to business development through the provision of skills training programmes to beneficiaries $(\mathrm{M}=4.00, \mathrm{SD}=0.64)$ as revealed in Table 1. Similarly, the group discussions showed that the interventions were highly relevant to the development of businesses in the communities through the skill training offered to the beneficiaries. In the words of participants from Daboase Area Council, "We have acquired skills training on business development in areas including petty trading, soap making, gari processing and animal rearing." Also, beneficiaries from Ekutuase agreed with the views expressed in Daboase Area. In support, beneficiaries of Ekutuase stated, "Through the Project, WVG offered us training on business skills. They taught us how to venture into businesses so that we obtain other sources of income". Thus, the results from the two approaches point to the fact that the Project was highly relevant to business development which is critical to the economic development of the District. This finding corroborates previous studies which established that development partners including NGOs are active in the provision of skill training on businesses (Adjei et al., 2012; Mondelez International \& Cocoa Life, 2014; USAID, 2009b).

\section{Relevance to access to microcredit facilities in the communities}

Credit facilities are important tools in micro-financing. Such facilities obtained through microfinance activities promote economic development (Biekart, 2008). In this study, it was established that Cocoa Life Project interventions of WVG had been highly relevant in expanding beneficiaries' access to microcredit facilities ( $\mathrm{M}=4.07$, $\mathrm{SD}=0.61$ ) in the District (Table 1). Also, all the beneficiaries who participated in the FGDs from the two Area Councils were very pleased with their access to credit facilities in the communities. The participants admitted that through the various VSLA formed by WVG they had been able to expand their access to credit facilities in the communities. On their part, beneficiaries from Ekutuase intimated, "Because we are members of the VSLA we can go for small loans to do business or pay school fees whenever the need arises. There is no pressure on us when we are repaying this loan." The FGDs with beneficiaries of Daboase Area also showed, "We get flexible loans 
from the VSLA at very minimal interest rates. We as members of the groups understand each other, so we do not require any collateral before accessing the credit facilities." It can be said that the interventions were very relevant to access to microcredit facilities. This result strengthens previous research by Hedayat and Ma'rof (2017) who discovered that development actors such as NGOs improve the economic well-being of communities through microcredit facilities they offer. Microcredit facilities help people to achieve their ability, skill and knowledge and take control over their own lives and finally become economically empowered (Biekart, 2008; Desai, 2005; FAO \& ILO, 2009).

\section{Development of agriculture in the communities}

Moreover, the study discovered that the Project has been highly relevant to the development of agriculture with respect to farming in the District. For instance, beneficiaries indicated that the interventions were highly relevant to skill training on modern farming practices $(\mathrm{M}=4.30, \mathrm{SD}=0.46)$. Also, the interventions were highly relevant in providing farm rehabilitation $(\mathrm{M}=4.26, \mathrm{SD}=0.45)$ in the communities. Also, the FGDs from both Councils showed that the interventions helped to improve agriculture in the communities through skill training, rehabilitation of farms and animal rearing. For instance, beneficiaries from Daboase Council said, "We have obtained so much assistance in the area of agriculture. They gave us fertilizers, and also taught us how to practice modern farming methods to increase farm produce." Also, at Ekutuase participants stated, "They engaged the Extension Agents to train us on new farming methods." Thus, the results from both the interview schedule and the

group discussions show that the Project was highly relevant to the development of agriculture in the communities. These findings support other studies (Nalere et al., 2015; Streeten, 1997) on the contribution of NGO activities to community development through agriculture. Similarly, in Nigeria, NGOs help to improve agriculture of communities (Enyioko, 2012). More so, applying modern technologies to boost agriculture is one of the reliable means of reducing poverty (Nelson, 2000).

\section{Financial literacy and income diversification}

Additionally, the interventions were observed to be highly relevant to financial literacy $(\mathrm{M}=4.03, \mathrm{SD}=0.90)$ and diversification of income sources $[\mathrm{M}=4.26, \mathrm{SD}=0.45]$ (Table 1). Moreover, the group discussions with the selected beneficiaries from Daboase Council indicated that the interventions were highly relevant to financial literacy and income diversification among communities. Similar observation was made by beneficiaries in the Ekutuase Area Council. For instance, beneficiaries from Ekutuase said, "WVG offered financial literacy training in the communities. Some of the interventions WVG provided can help us to diversify our sources of income." 
Thus, both the interview schedule and FGDs found that the interventions were highly relevant to financial literacy in the communities. These findings are similar to Mondelez International and Cocoa Life (2016) which observed that Cocoa Life Project improves financial literacy and diversification of income sources.

\section{Relevance to the creation of career opportunities}

On career opportunities in the communities, it was observed that the relevance of the Project too was moderate $(\mathrm{M}=3.40, \mathrm{SD}=1.08)$. In addition, the group discussions revealed that WVG effort made towards career opportunities in the District was moderate. However, participants from the two Area Councils indicated that more efforts needed to be made, especially to help offer career opportunities for the youth. In the words of the participants from Ekutuase Area, "Even though WVG created opportunities for the youth to get involved in cocoa farming as a career, not many of them are into it." Again, at Daboase it was observed, "Despite the efforts WVG made, many of the youth still do not appear to be much interested in career opportunities farming offers them." All the participants said that WVG has not done much to turn the fortunes of the teeming youth around. Some of the youth do not see any prospect in the cocoa farming as a source of employment in the District. This means that the Project was moderately relevant to the creation of career opportunities in the communities. Notwithstanding the moderate impact on job creation, this study converges with Nziane (2009) who found that development interventions impact job creation. Also, the result is essential because aside empowerment and security, job opportunities are one vital way that has complimentary and supplementary role in neutralisation of economic deprivation (Mehta, 2009). Besides, the study conforms to Adjei et al. (2012) and Hedayat and Ma'rof (2017) studies which found that NGOs' activities have contributed to creation of employment opportunities in many developing countries. Creation of career opportunities leads to economic empowerment.

\section{Relevance to health care services in the communities}

Furthermore, the beneficiaries believed that project interventions were moderately relevant to health care services in the communities $(\mathrm{M}=3.16, \mathrm{SD}=1.19)$. Discussions with some of the participants showed that though the Project was relevant to health care services of communities, the contribution was not very strong as they had hoped. In effect, it can be stated that the interventions were moderately relevant to health care services in the communities. Additionally, the FGDs with some beneficiaries in the Ekutuase Area showed, "Despite the awareness created about health care, the interventions have not very relevant to the health of community members." Besides, in Daboase, the study observed, "Health issues have received very low attention under the Cocoa Life Project. Our health is very important, so there should be some 
effective measures to tackle the health issues." Despite the moderate nature of the efforts, the findings on health care services strengthen other studies on the critical roles, other development agents such as NGOs play in health care services in most developing countries including Kenya and Ghana (Farrel \& Hartwell, 2008; USAID, 2009; Wamani, 2007). More so, the result on health care is consistent with Nalere et al. (2015) findings. Further, this study is vital because improved health care is crucial to the development programme (Omofonmwan \& Odia, 2009; Stiglitz, cited in AnnorFrempong, 2013).

\section{Relevance to water and sanitation in the communities}

More so, the relevance of the Project to access to safe and clean water in the communities was moderate $(\mathrm{M}=3.40, \mathrm{SD}=1.08)$ and creation of public awareness on sanitation practices $(\mathrm{M}=3.42, \mathrm{SD}=1.16$ ] [Table 1]. The group discussions with selected beneficiaries proved that even though communities had access to safe and clean water under the Project, they perceived such efforts by WVG as very moderate. On their part, beneficiaries from Daboase who took part in the FGDs indicated that access to safe and clean water in the communities has been very low. They complained, "The Project has contributed very little to the improvement of water and sanitation in the communities." Many communities are still in need of safe and clean drinking water." The beneficiaries from Ekutuase commented, "Not much has been done with respect to access to safe and clean water in the communities. Sanitation practice has also not seen much improvement. This is a major problem we wanted WVG and Cocoa Life to address for us." In effect, whilst the interview schedule showed some improvement in water and sanitation, the group discussions with selected beneficiaries indicated that no improvement has been seen. The findings based on the interview schedule affirm earlier studies (Chitongo, 2013; Dangah, 2012; Enyioko, 2012; WVI, 2010) which found that development actors such as NGOs help provide water and sanitation services to many communities worldwide. Access to safe drinking water supply and improved sanitation is key in effective development services (Adjei et al., 2012; Egyir, 2013; Enyioko, 2012). However, the results from the FGDs is a huge challenge to the realisation of Sustainable Development Goal [SDG] 6 (United Nations, 2016) which seeks to ensure increased access to clean water and improved sanitation.

\section{Relevance to behaviour change}

Behaviour change is important in any community development process. It is about alteration of attitudes and behaviours of individuals, families and communities on areas which are important to their lives (Zulas, 2009). In this study, it was observed that the project interventions moderately led to a change in behaviour towards community activities $(\mathrm{M}=3.39, \mathrm{SD}=1.08)$. Moreover, the results from the FGDs 
generally confirmed that the interventions had enabled some community members to change their behaviours towards community activities. Discussants from both Councils indicated that as a result of the interventions community members were able to get involved more in community activities than they had done prior to the delivery of the interventions. For instance, community members were more willing to contribute ideas to issues affecting their communities due to the interventions they received. Some beneficiaries were ever ready to help formulate action plans to improve their communities due to the education on Community Action Plan provided under the Cocoa Life Project interventions. However, the discussants opined that overall behaviour change especially at the community level was low. They added that despite the sensitisation programme on basic hygiene and sanitation among community members, many community members do not pay much attention to hygiene and sanitation practices. Besides, some farmers still relied on old farming practices despite the new farming methods they were taught under the Project. In spite of the concerns expressed, the findings generally help to accentuate the importance of behaviour change in development service delivery (USAID, 2014). Behaviour change has been an essential component of effective development communication approaches (FAO, 2010; Odoom, 2020; UNICEF, 2008).

\section{Community planning and local leadership}

Again, the interventions were moderately relevant to capacity building on community planning $(\mathrm{M}=3.14, \mathrm{SD}=1.21)$ and local leadership $(\mathrm{M}=3.40, \mathrm{SD}=1.08)$ in beneficiary communities. The results from the FGDs with the selected beneficiaries showed that the interventions were relevant to capacity building on community planning and local leadership. In the Daboase Area, beneficiaries commented, "The Project has helped our communities in terms of the support for community action plans and local leadership empowerment". The participants from Ekutuase Council said, "We have been taught how to plan for community development. Through Cocoa Life Project, many communities have members who can sit down and plan and develop actions and strategies for the communities. Also, we are able to take up leadership positions in the community." However, participants from both Councils were displeased that many beneficiaries are still not able to develop their own actions plans to improve their communities. They ascribed the situation to the way and manner interventions on community action plans were designed and implemented, with virtually no inputs from community leaders, members and opinion leaders. Regardless of the concern expressed during the FGDs, the Project was generally relevant to community planning and local leadership in WED which agrees with Mondelez International and Cocoa Life $(2014 ; 2016)$ which noted that Cocoa Life Project helps communities to develop their own action plans. However, Kamando (2014) calls for participation in effective community development interventions. 


\section{Theoretical Implications of the Study}

As already stated, the second part of this section presents the theoretical implications of the study. Key theories considered are the neoliberal, reasoned action, social cognitive and alternative development theories. The findings are also examined in the context of communication techniques and models. The theories and the models are relevant in communication and development. To start with, the study revealed that the various interventions in areas such as education, agriculture, opportunity for job creation, financial literacy, skill development, water and sanitation, and health could help improve the beneficiary communities. This result sustains the argument in favour of the neoliberal theory which calls for the need to allow other players such as NGOs and other development partners in the provision of development services (Lewis \& Kanji, 2009; Shivji, 2007; Yeboah, 2017). However, merely allowing other players into the development process without regard to the core areas of focus and the major obstacles to development will not lead to improvement in the communities. To clearly understand the major areas of development needs calls for increased participation of all stakeholders as reinforced by effective development communication frameworks (Mefalopulos, 2005; Odoom, 2020).

More so, the findings on behaviour change towards community activities are vital based on the theory of reasoned action and the social cognitive theory. For example, the willingness of community members to change their behaviours to ensure improvement in their communities validates the theory of reasoned action proposed by Fishbein and Ajzen. It also reinforces the place of Albert Bandura's social cognitive theory in development communication. As a vital theory in development communication, the theory of reasoned action posits that people act based on perceived advantages and disadvantages of their actions. This shows that people weigh the advantages and disadvantages before deciding whether or not to change their behaviours. Further, the social cognitive theory states that people learn through observation and the outcome of the observed behaviour. An observed behaviour will be modeled by a person if he/she is convinced of the outcome of the said behaviour. Thus, concerns about low behaviour change at the community level shows that not every member of the beneficiary communities was convinced about the advantages of changing their behaviours and the outcome of changing their behaviours. The failure of some farmers to adopt new farming methods seems to heighten the practical value of both the reasoned action theory and the social cognitive theory (Bandura, 2009). Clearly, there are concerns with the extent to which behaviour change communication approaches and principles underpinned the delivery of the interventions. To ensure a better change in behaviour in the context of development, there is the need for stakeholders to apply participatory communication approach in their activities (FAO, 2010; Mefalopulos, 2005; Odoom, 2020; UNICEF, 2008). 
Furthermore, the results on awareness creation on the importance of education in the communities, and public awareness on sanitation practices have implications for the practical manifestation of communication typologies and models. This is because awareness creation has been identified by Mefalopulos (2005), Quarry (2006) and UNICEF (2008) as one of the crucial communication models in the context of development practice. Thus, the use of awareness creation by WVG to promote community development in the District supports the positions of Mefalopulos (2005), Quarry (2006) and UNICEF (2008) on communication typologies. However, the inadequacy of awareness creation as a communication tool especially in the context of development is evident on the basis that it is often a one-directional flow of communication involving an organisation telling its audience what to do without regard to the inputs of the target audience (Mefalopulos, 2005; Odoom, 2020; Quarry, 2006).

Finally, the overall results of this study generally validate the practical relevance of the Alternative Development Theory (ADT). The ADT sees NGOs as potent actors to deliver development services to communities. In other words, inherent in the ADT is the belief that community development can be achieved with the active involvement of NGOs in development service delivery. This has been exemplified by WVG through its partnership with Mondelez International and Cocoa Life Division. By engaging in grass root development interventions, NGOs such as WVG stand the chance of earning the trust of the people living in such areas in a way that local governments may even find it difficult to replicate (Clark, 1991; Mohan, 2008). Thus, the intent of ADT can be realised only when development partners including NGOs purposefully design measures to engage in grass root development activities. However, concerns with regard to financial literacy training, community action plans, water and sanitation as well as the health care services as evidenced in this study suggest that there is more to be done by NGOs in order to make the ADT truly meaningful to development services. These concerns also suggest the need for development actors such as WVG and Cocoa Life Division to incorporate development communication tools and techniques in their service delivery. Development communication mechanisms are even more critical in the context of ADT which calls for increased attention to issues such as empowerment and participation.

\section{Conclusions}

Cocoa Life Project interventions implemented by WVG are generally relevant to the development of beneficiary communities. Through the Cocoa Life Project, WVG has been able to provide development interventions which are highly relevant to issues

such as education, business development, microcredit services, agriculture, livelihood diversification and financial literacy in beneficiary communities. However, WVG's 
contribution to other vital areas of community development such as career opportunities, health care services, water and sanitation is moderate. Besides, WVG's interventions in the areas of community planning, local leadership, support for community action and behaviour change towards community activities moderately improve beneficiary communities. Awareness creation is one essential tool WVG uses to promote community development in the District. Also, beneficiary communities have diverse development needs which can better be appreciated using relevant development communication strategies. Despite the efforts made by WVG, many communities still do not have access to safe and clean water and improved sanitation facilities. There are also concerns with health care services and the efforts to promote behaviour change at the community level. Again, training on development of community action plans is designed and implemented with very little input from beneficiaries. These concerns generally reinforce the need for development partners to pay increased attention to communication models and approaches which are vital in the delivery of development services. In other words, the results of this study have implications for development communication theories, strategies, models and approaches. It is noteworthy that the views of officers of WVG and Cocoa Life Division are not captured in the findings since they were not involved in the study. It is suggested that further studies be conducted on Cocoa Life Project by other researchers using beneficiary communities in other districts in Ghana and beyond. Such studies should also consider the views of other stakeholders especially officials of implementing partners.

\section{References}

ActionAid International (2013), Action for Children's Rights in Education: End of project evaluation report. Accessed on 23/07/17, from: www.actionaid.org

Adjei, P. O. W., Agyemang, S., \& Afriyie, K. (2012), Non-Governmental Organisations and Rural Poverty Reduction in Northern Ghana: Perspectives of Beneficiaries on Strategies, Impact and Challenges. Journal of Poverty Alleviation and International Development, 3(2) 47-73

Agunga, R., Atyeru, S. B., \& Annor-Frempong, F. (2006), Communication for local participation in project planning: A study of rural development workers in Ghana and Nigeria. Journal of Development Communication, 16(2) 1-14.

Alfasi, N. (2003), Is public participation making urban planning more democratic? The Israeli experience. Planning Theory \& Practice, 4(2) 185-202.

Annor-Frempong, F. (2013), Supervised Enterprise Projects as a community development tool. Case Studies on Human Resource Development in Agricultural Extension. Accessed on 12/02/18, from: www.measextension.org/meas-offers/case-studies 
Bandura, A. (2009), Social and policy implications of social cognitive theory. In M. Marks, S. Donaldson, \& B. Cambel (Eds.). Social psychology anprogram/policy evaluation. New York: Guildford.

Banks, N., \& Hulme, D. (2012), The role of NGOs and civil society in development and poverty reduction. BWPI Working Paper 171. Manchester: The Brooks World Poverty Institute

Barr, A., Fafchamps, M., \& Trudy, O. (2005), The governance of NGOs in Uganda. World Development, 33(4), $657-679$.

Barrett, C. B., Reardon, T., \& Webb, P. (2001), Non-farm income diversification and household livelihood strategies in rural Africa: Concepts, dynamics, and policy implications. Food Policy, 26, 315-331.

Biekart, K. (2008), 'Learning from Latin America: Recent trends in European NGO policymaking'. Chapter 4 in A. Bebbington, S. Hickey, and D. Mitlin (eds), Can NGOs Make a Difference? The Challenge of Development Alternatives. London: Zed books, pp. 71-89.

Brass, N. J. (2010), Surrogates for Government? NGOs and the State in Kenya. PhD dissertation. University of California, Berkeley.

Brass, J. N. (2011), Blurring boundaries: The integration of NGOs into governance in Kenya. An International Journal of Policy, Administration, and Institutions, 25(2), 209-235.

Brass, J. N. (2012), Why do NGOs go where they go? World Development, 40(2), 387401

Brown, C.K, (2006), Rural Development in Ghana. Accra: University press.

Chitongo, L. (2013), The contribution of NGOs to rural development: The case of Catholic Relief Services protecting vulnerable livelihoods programme in Zimbabwe. Asian Journal of Management Sciences and Education, 2 (3), 144-143.

Christie, F., \& J. Hanlon (2001), Mozambique and the Great Flood of 2000. Oxford: James Currey.

Clark, J. (1991), Democratizing development: The role of voluntary organisations. London: Kumarian.

Dangah, M. M. (2012), The role of NGOs in the provision of water and sanitation in Northern Ghana: The case of ProNet in the Nadowli District. An unpublished Master's Thesis, Kwame Nkrumah University of Science and Technology, Kumasi.

Desai, V. (2005), NGOs, gender mainstreaming, and urban poor communities in Mumbai. Gender and Development, 13(2), 90-98.

Edwards, M., \& Hulme, D. (1995), NGOs-performance and accountability: Beyond the Magic Bullet. London: Earthscan. 
Egyir, B. B. (2013), The role of NGOs in rural development: A case study of World Vision Ghana in Mfantesman district. An unpublished dissertation submitted to the Kwame Nkrumah University of Science and Technology, Kumasi.

Enyioko, N.C. (2012), Role of Non-Governmental Organisations (NGOs) in rural development: Study of the six listed NGOs in Rivers State, Nigeria. Medonice Consulting and Research Institute

Epstein, G. S., \& Gang, I. N. (2006), Contests, NGOs, and decentralizing aid. Review of Development Economics, 10(2), 285-296.

Farrel, J., \& Hartwell, A. (2008), Planning for successful Alternative schooling: A possible route to education for all, International Institute for Educational Planning.

FAO (2010), Tracking initiatives in communication for development in the Near East. Rome: FAO.

Haines, A. (2009), Asset-Based Community Development. In: Phillips, R. \& Pittman, R. H. (eds.). An Introduction to Community Development. London: Routledge. p. 38-48.

Hedayat, A. N., \& Ma'rof, B. R. (2010), The role of NGOs in promoting empowerment for sustainable community development. J Hum Ecol, 30(2), 8592.

Hearn, J. (2007), Roundtable: African NGOs: The new compradors? Development and Change, 38(6), 1095-1110.

Kamando, A. N. (2014), Government-community partnership in the provision of education in Rural Tanzania. PhD thesis, University of Glasgow. Accessed on 23/02/18, from: http://theses.gla.ac.uk/5294/

Khatun, D., \& Roy, B. C. (2012), Rural livelihood diversification in West Bengal: Determinants and constraints. Agric Econs Res Rev, 25(1).

Kombian, E. F. (2008), Education and girl-child empowerment: The case of Bunkpurugu/Yunyoo District in Northern Ghana. An mphil thesis, Faculty of Social Sciences, University of Tromso.

Ledwith, M. (2011), Community development: A critical approach (2nd Ed.). Bristol: The Policy Press.

Lewis, D. (2005), Actors, ideas and networks: Trajectories of the nongovernmental in development studies. In U. Kothari (Ed.), A radical history of development studies. London: Zed books.

Lewis, D., \& Kanji, N. (2009), Non-governmental organisations and development. London and New York: Routledge.

Mefalopulos, P. (2005), Media and global change; rethinking Communication for Development. Nordicom and CLACSO.

Mondelez International (2013), Cocoa Life committing to empowering women through community-centered programmes. 
Mondelez International and Cocoa Life (2013), Cocoa Life Guidance Document. July 2013 publication.

Mondelez International Progress Report (2015), The call for well-being. 2015 Progress Report. Mondelez International

Murray, W. E., \& Overton, J. D. (2011), Neoliberalism is dead, long live neoliberalism? Neostructuralism and the international aid regime of the 2000s. Progress in Development Studies, 11(4), 307-319.

Nelson, P. J. (2000), Heroism and Ambiguity: NGO Advocacy in International Policy, Development in Practice. 10. Pp 478-490.

Nziane, E. M. (2009), Community development projects and livelihoods in Lepelle-Nkumpi Municipality of Limpopo Province of South Africa. An unpublished Dissertation, Turfloop Graduate School of Leadership, Faculty of Management Sciences.

Odoom, D. (2016), Conceptualising decentralisation: Reflecting on some existing literature. Applied Research Journal, 1(4), 21-38.

Odoom, D. (2020), Understanding Development Communication: A Review of Selected Literature. E-Journal of Humanities, Arts and Social Sciences, 1 (1), 37-48.

Odoom, D., Yeboah, R., Opoku, E., \& Osei-Wusu, P. (2018), Appreciating the challenge of community participation in NGO-led development interventions: An analysis of some existing literature. International Journal in Management and Social Science, 6(10), 30-52.

Okorley, E. L., \& Nkrumah, E. E. (2012), Organisational factors influencing sustainability of local non-governmental organisations: Lessons from a Ghanaian context. International Journal of Social Economics, 39(5), 330-341.

Oladipo, F., \& Adekunle, O. (2010), Empirical determination of socio-economic status and its relationship with selected characteristics of rural male farmers in Kwara state, Nigeria. A Research Journal of Agriculture and Biological Sciences, 6(1), 64-76.

Omofonmwan, S. I., \& Odia, L. O. (2009), The role of Non-Governmental Organisations in community development: Focus on Edo State-Nigeria. Anthropologist, 11(4), 247-254.

Opoku, E., Kyeremeh, C., \& Odoom, D. (2014), Local Revenue Mobilisation Mechanisms: Evidence from the Abura-Asebu-Kwamankese District in Ghana. Journal of Developing Country Studies, 4 (26), 255-266.

Quarry, W. (2006), Decision makers do want communication - what they may not want is participation. Paper prepared for the 1st World Congress on Communication for Development. The Communication Initiative.

Rahman, S., \& Shaheen, A. (2014), Determinants of livelihood choices: An empirical analysis from rural Bangladesh. Journal of South Asian Development, 9(3), 287-308 
Russell, C. (2009), Communities in control - developing assets. In: Carnegie UK Trust (ed.). The first European Asset-based Community Development Conference. Liverpool, June 2009.

Shivji, G. I. (2007), The silences in NGO discourse: The role and future of NGOs in Africa. Oxford: Fahamu.

Streeten, P. (1997), Non-governmental Organisations and Development. Annals of the American Academy of Political and Social Science, 554, 193-210.

Stromquist, N. P. (2002), NGOs in a new paradigm of civil society. Current Issues in Comparative Education, 1(1), 62-67.

Swastik (2012), Five most essential elements of community development programme in India. Accessed on 14/05/18 from: www.preservearticles.com/20110509641/5-most essential-elements-of-acommunity-development-programme-in-india.html

Tett, I. (2010), Community Education, Leaning and Development (3rd ed.).Edinburgh: Dunedin Academic Press.

UNICEF (2008), Communication for Development and Social Change. London: Sage Publications.

USAID (2009b), NGO Sustainability Index for Sub-Saharan Africa. Pp 64-66.

USAID (2014), Engaging communities for behavior change. Haryana: Public Health Foundation.

Yeboah, R. (2017), Public private partnership in solid waste management in Sunyani Municipality. Mphil thesis, IDS, University of Cape Coast.

Zakaria, J. (2011), An evaluation of NGO-led development interventions and their sustainable management in the Savelugu-Nantong District. An unpublished thesis, KNUST, Kumasi.

Zulas, A. L. (2009), Environmental change: The application of three theories of behavior change on recycling behavior and ecological values. Retrieved from Pro-Quest Dissertations and Thesis. (ID: 195484701) 